\title{
Proinflammation of Aging Central Arteries: A Mini-Review
}

\author{
Mingyi Wang Robert E. Monticone Edward G. Lakatta \\ Laboratory of Cardiovascular Science, National Institute on Aging, National Institutes of Health, \\ Biomedical Research Center (BRC), Baltimore, Md., USA
}

\section{Key Words}

Aging · Arterial remodeling · Proinflammation .

Cellular phenotype

\begin{abstract}
Arterial aging is a cornerstone of organismal aging. The central arterial wall structurally and functionally remodels under chronic proinflammatory stress over a lifetime. The lowgrade proinflammation that accompanies advancing age causes arterial wall thickening and stiffening. These structural and functional alterations are consequences of adverse molecular and cellular events, e.g. an increase in local angiotensin II signaling that induces an inflammatory phenotypic shift of endothelial and smooth muscle cells. Thus, interventions to restrict proinflammatory signaling are a rational approach to delay or prevent age-associated adverse arterial remodeling.

๑ 2014 S. Karger AG, Basel
\end{abstract}

\section{Introduction}

Aging exponentially increases the morbidity and mortality of quintessential cardiovascular diseases, including hypertension and atherosclerosis, which are closely correlated with intimal-medial thickening and arterial stiff- ening [1-3]. Studies from animal experiments and human tissue samples demonstrate that age-associated arterial structural and functional changes are the consequence of a proinflammatory phenotypic shift of the arterial cells, including endothelial cells (ECs), vascular smooth muscle cells (VSMCs) and (myo)fibroblasts (tables 1, 2) [2-5]. These cellular alterations are closely associated with chronic activation of the angiotensin II (Ang II) signaling cascade [5]. The molecular and cellular events drive arterial wall elastin fragmentation, fibrosis, calcification, glycation, and amyloidosis with advancing age (fig. 1) [2-5].

Proinflammation in the arterial wall is an autoregulated Ang II signaling phenomenon in response to pathophysiological conditions, facilitating 'full-blown' inflammation [5]. This Ang II signaling in the arterial wall with aging originally appears to serve a protective/adaptive biological goal overcoming the changes in hemodynamics and humoral factors, and eventually sets a fertile stage for the initiation and progression of the pathogenesis of hypertension and atherosclerosis in the elderly (fig. 1; table 2) $[2,3,5]$. The existing proinflammation lowers the threshold for 'battle signaling triggers' and therefore augments arterial inflammation and increases the incidence of thrombosis, calcification, and lipid pool formation in the advanced arterial lesions with a clinical presentation in the elderly population $[1,6-10]$. Thus, suppression of age-associated arterial proinflammation is a rational ap-

\section{KARGER}

E-Mail karger@karger.com www.karger.com/ger
(C) 2014 S. Karger AG, Basel

0304-324X/14/0606-0519\$39.50/0
Mingyi Wang, $\mathrm{MD}, \mathrm{PhD}$, or Edward G. Lakatta, $\mathrm{MD}$

Laboratory of Cardiovascular Science, National Institute on Aging National Institutes of Health, Biomedical Research Center (BRC) BRC, 251 Bayview Blvd, Baltimore, MD 21224 (USA)

E-Mails mingyiw@grc.nia.nih.gov or lakattae@grc.nia.nih.gov 


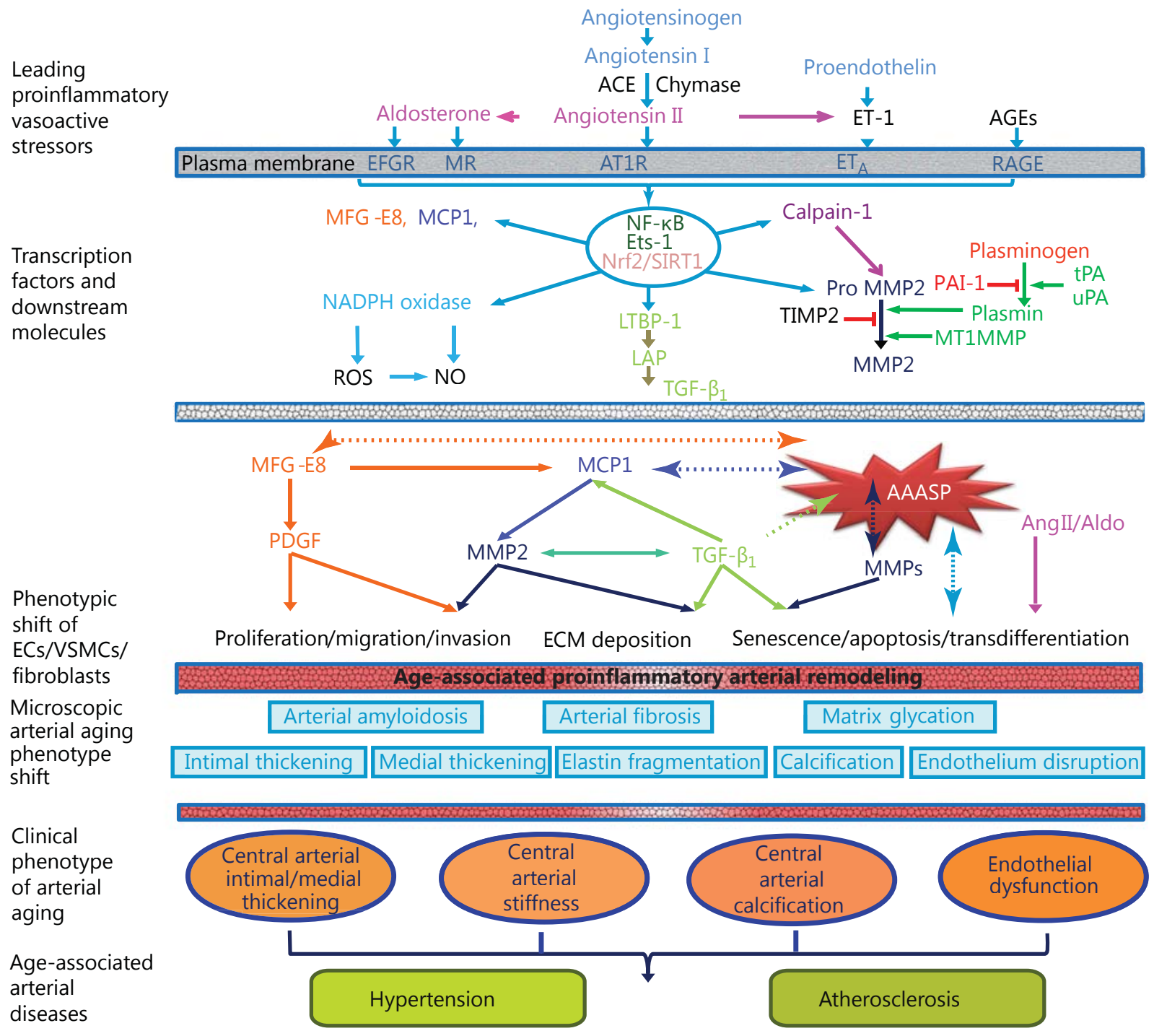

Fig. 1. Diagram of age-associated proinflammatory arterial remodeling, modified from Wang et al. [2]. Signal Cascades: (i) The chronic proinflammatory profile within central arteries with advancing age is characterized by alterations in signaling systems that include Ang II signaling via its receptor $\mathrm{AT}_{1}$, aldosterone/MR, $\mathrm{ET}-1 / \mathrm{ET}_{\mathrm{A}}$ signaling. AGEs recruit inflammatory molecules by interaction with their cellular transduction receptor for AGEs (RAGE). (ii) Proinflammatory transcription factors such as NF- $\mathrm{kB}$ and Ets- 1 are activated within the aging arterial wall, whereas protective factors such as Nrf2 and SIRT1 are reduced. (iii) Downstream signaling molecules include MFG-E8, MMPs, calpain-1, MCP-1, TGF- $\beta_{1}$. Activation of calpain-1, MMPs, TGF- $\beta_{1}$ and NADPH oxidase increases whereas NO bioavailability decreases with advancing age. (iv) Differences of AAASP are observed in the

cytokine secretion profile of primary VSMCs derived from young and aged non-human primates. Compared to young VSMCs, old cells exhibit secretion of increased amounts of MFG-E8, MCP-1, MMP2 and TGF- $\beta_{1}$. Concurrent proinflammatory proliferation, migration, secretion, senescence, and ECM remodeling are characteristic features of ECs, VSMCs, and (myo)fibroblasts within the aged arterial wall. (v) Microscopic arterial aging changes include disruption of the endothelium, intima-media thickening, arterial amyloidosis, fibrosis, elastin fracture, matrix glycoxidative modifications, and calcification that are consequences of the enhanced signaling via these receptor signaling cascades. (vi) There is growing evidence that a significant interaction exists between aging and hypertension/atherosclerosis.

(For second part of legend see next page.) 
proach, which not only retards adverse remodeling, but also curtails the epidemic of hypertension and atherosclerosis in the older persons of our population.

\section{Molecular Histology of Arterial Aging}

Studies from immunostaining demonstrate that within the aging arterial wall: Ang II, aldosterone (Aldo), endothelin-1 (ET-1), calpain-1, matrix metalloproteinase type II (MMP-2), monocyte chemoattractant protein1 (MCP-1), transforming growth factor- $\beta_{1}\left(\mathrm{TGF}-\beta_{1}\right)$, milk fat globule EGF-8 (MFG-E8), tissue necrosis factor- $\alpha$ (TNF- $\alpha$ ), plasmin, platelet-derived growth factor (PDGF), reactive oxygen species (ROS), and advanced glycation end-products (AGEs) are enhanced; in contrast, bioavailability of arterial nitric oxide (NO) is decreased (table 1) [2-5]. In addition, receptors for these ligands, i.e. $\mathrm{AT}_{1}$, mineralcorticoid receptor (MR), TGF- $\beta$ type II (T $\beta$ IIR), integrins, $\mathrm{C}-\mathrm{C}$ chemokine receptor type 2 (CCR2), endothelin receptor (ER) and epidermal growth factor, are upregulated with aging (table 1) [2-5]. Furthermore, this receptor-activating signaling leads to an increase in proinflammatory transcription factor nuclear factor $\kappa$-lightchain-enhancer of activated B cells (NF- $\mathrm{kB}$ ) and the v-ets erythroblastosis virus E26 oncogene homolog 1 (Ets-1) within the arterial wall with aging while anti-inflammatory transcription factor nuclear factor NF-E2-related factor 2 (Nrf2) and silent information regulation 2 homo$\log 1$ (SIRT1) become reduced (table 1) [2-5].

\section{(Second part of legend to figure 1.)}

Abbreviations and Acronyms: Ang II = Angiotensin II; ET-1 = endothelin-1; MMPs = matrix metalloproteases; $\mathrm{MCP}-1$ = monocyte chemoattractant protein -1 ; CCR $2=\mathrm{C}-\mathrm{C}$ chemokine receptor type 2 ; TGF- $\beta_{1}=$ transforming growth factor $\beta_{1}$; T $\beta$ IIR $=$ TGF- $\beta$ receptor type II; NADPH oxidase $=$ nicotinamide adenine dinucleotide phosphate oxidase; $\mathrm{NO}=$ nitric oxide; TNF- $\alpha=$ tumor necrosis factor- $\alpha$; ICAM = intercellular adhesion molecule; MFG-E8 = milk fat globule epidermal growth factor-8; PDGF = platelet-derived growth factor; PDGFR $=$ PDGF receptor; $\mathrm{tPA}=$ tissue plasminogen activator; $\mathrm{uPA}=$ urine plasminogen activator; PAI- $1=$ plasminogen activator inhibitor-1; AGEs = advanced glycation endproducts; RAGE = receptor for advanced glycation end-products; $\mathrm{IL}=$ interleukin; $\mathrm{MR}=$ mineral corticoid receptor; $\mathrm{NF}-\kappa \mathrm{B}=$ nuclear factor $\kappa$-light-chain-enhancer of activated B cells; Ets- $1=\mathrm{v}$-ets erythroblastosis virus E26 oncogene homolog 1; Nrf2 = NF-E2related factor 2; SIRT1 = silent information regulation 2 homolog $1 ; \mathrm{EC}=$ endothelial cell; IMT = intima-media thickening; $\mathrm{FN}=$ fibronection; VSMC = vascular smooth muscle cell; LTBP = latent TGF-binding protein; LAP = latency TGF-associated protein.

Proinflammation of Aging Central Arteries

\section{Arterial, Cellular, and Molecular Events with Aging}

Age-associated proinflammatory molecular remodeling and signaling alter the phenotype of vascular cells, including ECs, VSMCs, and (myo)fibroblasts, facilitating adverse arterial remodeling with aging (table 2; fig. 1) [2-5].

\section{Intima}

The intima, which lies between the luminal surface and the internal elastic lamina of the artery, is a 'frontline stress field' for the arterial wall. Age predominantly alters

Table 1. Distribution and cellular sources of inflammation-associated molecules in the old compared to the young central arterial wall.

\begin{tabular}{|c|c|c|c|c|c|}
\hline Molecule & $\begin{array}{l}\text { Thick- } \\
\text { ened } \\
\text { intima }\end{array}$ & $\begin{array}{l}\text { Degen- } \\
\text { erated } \\
\text { media }\end{array}$ & $\begin{array}{l}\text { Expanded } \\
\text { adventitia }\end{array}$ & $\begin{array}{l}\text { Cell } \\
\text { origin }\end{array}$ & Species \\
\hline Ang II & $\uparrow \uparrow$ & $\uparrow$ & $?$ & E, S, F & $\mathrm{M}, \mathrm{R}, \mathrm{H}, \mathrm{NH}$ \\
\hline ACE-1 & $\uparrow \uparrow$ & $\uparrow$ & $?$ & $\mathrm{E}, \mathrm{S}, \mathrm{F}$ & $\mathrm{M}, \mathrm{R}, \mathrm{H}, \mathrm{NH}$ \\
\hline Chymase & $?$ & ? & $\uparrow \uparrow$ & $\mathrm{Ma}$ & $\mathrm{M}, \mathrm{NH}$ \\
\hline ET-1 & $\uparrow \uparrow$ & $\uparrow$ & $?$ & E, S, F & $\mathrm{M}, \mathrm{R}, \mathrm{Ra}$ \\
\hline MFG-E8 & $\uparrow$ & $\uparrow$ & $?$ & $\mathrm{E}, \mathrm{S}, \mathrm{F}$ & $\mathrm{R}, \mathrm{H}, \mathrm{NH}$ \\
\hline TGF- $\beta_{1}$ & $\uparrow$ & $\uparrow$ & $?$ & E, S, F & $\mathrm{M}, \mathrm{R}, \mathrm{H}$ \\
\hline MCP-1 & $\uparrow$ & $\uparrow$ & $?$ & $\mathrm{E}, \mathrm{S}, \mathrm{F}$ & $\mathrm{M}, \mathrm{R}, \mathrm{Ra}, \mathrm{H}, \mathrm{NH}$ \\
\hline MMP-2/9 & $\uparrow$ & $\uparrow$ & $?$ & E, S, F & $\mathrm{M}, \mathrm{R}, \mathrm{H}, \mathrm{NH}$ \\
\hline Calpain-1 & $\uparrow$ & $\uparrow$ & $?$ & $\mathrm{E}, \mathrm{S}, \mathrm{F}$ & $\mathrm{R}, \mathrm{H}$ \\
\hline eNOS & $\downarrow \uparrow$ & $\downarrow \uparrow$ & $?$ & $\mathrm{E}, \mathrm{S}, \mathrm{F}$ & $\mathrm{M}, \mathrm{R}, \mathrm{H}, \mathrm{NH}$ \\
\hline iNOS & $\uparrow$ & $\uparrow$ & $?$ & E, S, F & $\mathrm{R}$ \\
\hline PDGF/R & $\uparrow$ & $\uparrow$ & $?$ & $\mathrm{E}, \mathrm{S}, \mathrm{F}$ & $\mathrm{M}, \mathrm{R}$ \\
\hline $\mathrm{tPA}$ & $\uparrow \uparrow$ & $\uparrow$ & $?$ & $\mathrm{E}, \mathrm{S}, \mathrm{F}$ & $\mathrm{R}$ \\
\hline $\mathrm{uPA}$ & $\uparrow \uparrow$ & $\uparrow$ & $?$ & E, S, F & $\mathrm{R}$ \\
\hline PAI-1 & $\downarrow \downarrow$ & $\downarrow$ & $?$ & E, S, F & $\mathrm{R}$ \\
\hline AGEs & $\uparrow \uparrow$ & $\uparrow$ & $?$ & PTM & $\mathrm{M}, \mathrm{R}, \mathrm{H}, \mathrm{NH}$ \\
\hline ICAM & $\uparrow \uparrow$ & $\uparrow$ & $?$ & E, S, F & $\mathrm{M}, \mathrm{R}, \mathrm{H}, \mathrm{NH}$ \\
\hline TNF- $\alpha_{1}$ & $\uparrow \uparrow$ & $\uparrow$ & $?$ & E, S, F & $\mathrm{M}, \mathrm{R}, \mathrm{H}, \mathrm{NH}$ \\
\hline IL-1/-6/-8 & $\uparrow$ & $\uparrow$ & $?$ & $\mathrm{E}, \mathrm{S}, \mathrm{F}$ & $\mathrm{M}, \mathrm{R}, \mathrm{Ra}, \mathrm{H}, \mathrm{NH}$ \\
\hline $\mathrm{AT}_{1}$ & $\uparrow$ & $\uparrow$ & $?$ & E, S, F & $\mathrm{M}, \mathrm{R}, \mathrm{H}, \mathrm{NH}$ \\
\hline T $\beta$ IIR & $\uparrow$ & $\uparrow$ & $?$ & $\mathrm{E}, \mathrm{S}, \mathrm{F}$ & $\mathrm{R}, \mathrm{Ra}$ \\
\hline MR & $\uparrow$ & $\uparrow$ & $?$ & E, S, F & $\mathrm{M}, \mathrm{R}, \mathrm{Ra}, \mathrm{H}, \mathrm{NH}$ \\
\hline Coll I/II/III & $\uparrow \uparrow$ & $\uparrow$ & $?$ & $\mathrm{E}, \mathrm{S}, \mathrm{F}$ & $\mathrm{M}, \mathrm{R}, \mathrm{Ra}, \mathrm{H}, \mathrm{NH}$ \\
\hline$N F-\kappa B$ & $\uparrow$ & $\uparrow$ & $?$ & $\mathrm{E}, \mathrm{S}, \mathrm{F}$ & $\mathrm{M}, \mathrm{R}, \mathrm{Ra}, \mathrm{H}, \mathrm{NH}$ \\
\hline Ets-1 & $\uparrow$ & $\uparrow$ & $?$ & E, S, F & $\mathrm{R}$ \\
\hline Nrf2 & $\downarrow$ & $\downarrow$ & $?$ & $\mathrm{E}, \mathrm{S}, \mathrm{F}$ & $\mathrm{M}, \mathrm{R}, \mathrm{NH}$ \\
\hline SIRT1 & $\downarrow$ & $\downarrow$ & $?$ & E, S, F & $\mathrm{M}, \mathrm{R}, \mathrm{H}, \mathrm{NH}$ \\
\hline
\end{tabular}

See figure 1 for abbreviations and acronyms. $\uparrow \uparrow=$ Predominantly increase; $\uparrow=$ increase; $\downarrow$ = decrease; $\downarrow \uparrow=$ increase or decrease; ? = unknown. $\mathrm{E}=$ Endothelial cells; $\mathrm{S}=$ vascular smooth muscle cells; $\mathrm{F}=$ (myo)fibroblasts; $\mathrm{Ma}=$ mast cells; $\mathrm{M}=$ mice; $\mathrm{R}=$ rats; $\mathrm{Ra}=$ rabbits $\mathrm{H}=$ humans $; \mathrm{NH}=$ nonhumans $; \mathrm{PTM}=$ post-translational modification. 
Table 2. Molecular and cellular remodeling; modified from Wang et al. [3]

\begin{tabular}{|c|c|c|c|c|c|c|c|}
\hline & \multicolumn{4}{|l|}{ Aging } & \multirow{2}{*}{$\begin{array}{l}\text { Hyper- } \\
\text { tension }\end{array}$} & \multirow{2}{*}{$\begin{array}{l}\text { Athero- } \\
\text { sclerosis }\end{array}$} & \multirow{2}{*}{$\begin{array}{l}\text { Ang II } \\
\text { Signaling }\end{array}$} \\
\hline & $\begin{array}{l}\text { humans } \\
>56 \text { vs. } \\
<20 \text { years }\end{array}$ & $\begin{array}{l}\text { monkeys } \\
15-20 \text { vs. } \\
<10 \text { years }\end{array}$ & $\begin{array}{l}\text { rats } \\
24-30 \text { vs. } \\
3-8 \text { months }\end{array}$ & $\begin{array}{l}\text { rabbits } \\
2-6 \text { years vs. } \\
<10 \text { months }\end{array}$ & & & \\
\hline \multicolumn{8}{|c|}{ Inflammation-association molecules } \\
\hline Local Ang II/AT 1 & $\uparrow$ & $\uparrow$ & $\uparrow$ & $?$ & $\uparrow$ & $\uparrow$ & $\uparrow$ \\
\hline Calpain-1 & $\uparrow$ & $\uparrow$ & $\uparrow$ & $?$ & $\uparrow$ & $\uparrow$ & $\uparrow$ \\
\hline MCP-1/CCR2 & $\uparrow$ & $\uparrow$ & $\uparrow$ & $\uparrow$ & $\uparrow$ & $\uparrow$ & $\uparrow$ \\
\hline TGF- $\beta_{1} /$ T $\beta$ IIR & $\uparrow$ & $\uparrow$ & $\uparrow$ & $\uparrow$ & $\uparrow$ & $\uparrow$ & $\uparrow$ \\
\hline NADPH oxidase & $\uparrow$ & $\uparrow$ & $\uparrow$ & $\uparrow$ & $\uparrow$ & $?$ & $\uparrow$ \\
\hline NO bioavailability & $\downarrow$ & $\downarrow$ & $\downarrow$ & $\downarrow$ & $\downarrow$ & $\downarrow$ & $\downarrow$ \\
\hline TNF- $\alpha_{1}$ & $\uparrow$ & $\uparrow$ & $\uparrow$ & $\uparrow$ & $\uparrow$ & $\uparrow$ & $\uparrow$ \\
\hline AGEs/RAGE & $\uparrow$ & $\uparrow$ & $\uparrow$ & $\uparrow$ & $\uparrow$ & $\uparrow$ & $\uparrow$ \\
\hline IL-1/-6/-8 & $\uparrow$ & $?$ & $\uparrow$ & $\uparrow$ & $\uparrow$ & $\uparrow$ & $\uparrow$ \\
\hline MR & $?$ & $?$ & $\uparrow$ & $?$ & $?$ & $\uparrow$ & $\uparrow$ \\
\hline$N F-\kappa B$ & $\uparrow$ & $\uparrow$ & $\uparrow$ & $\uparrow$ & $\uparrow$ & $\uparrow$ & $\uparrow$ \\
\hline Ets-1 & $?$ & $?$ & $\uparrow$ & $?$ & $\uparrow$ & $\uparrow$ & $\uparrow$ \\
\hline SIRT1 & $\downarrow$ & $?$ & $\downarrow$ & $?$ & $\downarrow$ & $\downarrow$ & $\downarrow$ \\
\hline \multicolumn{8}{|c|}{ Cellular-matrix structure and function } \\
\hline EC dysfunction & $\uparrow$ & $\uparrow$ & $\uparrow$ & $\uparrow$ & $\uparrow$ & $\uparrow$ & $\uparrow$ \\
\hline Diffuse IMT & $\uparrow$ & $\uparrow$ & $\uparrow$ & $\uparrow$ & $\uparrow$ & $\uparrow$ & $\uparrow$ \\
\hline Stiffness & $\uparrow$ & $\uparrow$ & $\uparrow$ & $\uparrow$ & $\uparrow$ & $\uparrow$ & $\uparrow$ \\
\hline Matrix & $\uparrow$ & $\uparrow$ & $\uparrow$ & $\uparrow$ & $\uparrow$ & $\uparrow$ & $\uparrow$ \\
\hline
\end{tabular}

the cellular and molecular quality and quantity of this zone through the Ang II signaling pathway [2-5]. With advancing age, VSMCs infiltrate into the subendothelial space, the modified extracellular matrix (ECM) expands via glyoxylation, and proinflammarory molecules such as Ang II accumulate in the thickened intima, contributing to EC apoptosis and senescence [2-5].

\section{Endothelial Apoptosis}

The actions of Ang II induces increases in TNF- $\alpha$, calpain-1, MCP-1, ROS, and MFG-E8 and decreases the NO bioavailability and SIRT1 activity, presenting a proinflam- matory molecular stress into the endothelia of aged rats, monkeys and humans [2-5]. These molecular signals lead to caspase-3/-9 activation and consequently DNA cleavage, resulting in EC apoptosis, a cellular event of NF- $\mathrm{KB}$ activation that has been observed in the old endothelium in vivo and is closely associated with a decline of endothelial-dependent flow-induced dilatation [11-13].

\section{Endothelial Senescence}

Ang II and ROS molecular signals induce telomere shortening or damage endothelial mitochondrial DNA, triggering senescence via an activation of the DNA dam- 
age ataxia-telangiectasia-mutated protein (ATM)/CHK2/ p53/p21 signaling pathway [14-16]. Importantly, EC senescence within the old arterial wall is accelerated by glycemic conditions [15]. The extent of EC senescence is closely associated with endothelial dysfunction [15-17].

\section{Media}

The media, a patterned region between the internal and external elastic lamina of central arteries, provides the vessel's second line of defense. It is composed of a circumferential arrangement of VSMCs, the predominant cell type around the elastic lamina and other ECM such as collagen. The morphology and orientation of aged VSMCs are considerably varied and their behavior is substantially heterogeneous such as proliferation/invasion/ senescence/apoptosis, which is closely associated with proinflammation [18-22]. Importantly, with advancing age, the medial elastin laminae become eroded and fractured, and collagens, in particular collagen types I, III, and IV, are deposited and degraded around VSMCs [23, 24].

\section{VSMC Senescence and Secretion}

Abundant Ang II is present around or within VSMCs within the old arterial wall. Some aortic VSMCs of 34-month-old rats (old) are polyploid and larger in size than those in the aorta from 3-month-old rats, and are enriched in NADPH oxidase 4 (NOX4) and p16 (INK4a) $[19,20]$. Survivin, a chromosome messenger protein, decreases in the majority of such polyploid cells, and a cellcycle arrest status known as senescence occurs in these cells [19]. These findings suggest that Ang II induces VSMC senescence $[25,26]$. Indeed, chronic exposure to Ang II increases DNA damage in VSMCs and induces senescence, which can be substantially reduced by overexpression of human telomerase [26]. This scenario is known as replicative senescence. Furthermore, acute exposure to Ang II is also associated with increased sensing, transducing, and effecting the signaling of DNA damage: p53 acetylation and p21 activation in senescent VSMCs, independent of telomere attrition [26]. Overexpression of human telomerase in this instance does not retard senescence [26]. This scenario is referred to as stress-induced premature senescence (SIPS). In addition, alterations of the ECM may facilitate the senescence of VSMCs induced by Ang II [27]. Indeed, VSMCs isolated from collagenaseresistant collagen type I mutant mouse aorta, a premature aging model, are susceptible to Ang II-induced senes-

Proinflammation of Aging Central Arteries cence via upregulation of p16 and p21 [27]. Strikingly, these mutant mice have hypertension and a shortened lifespan [27].

An age-associated arterial secretory phenotype (AAASP) is observed in the cytokine secretion profile of primary VSMCs derived from old non-human primates (fig. 1) [28]. Old cells secrete more interleukin-1 $\beta$ (IL-1 $\beta$ ), interleukin-6 (IL-6), MCP-1, and TNF- $\alpha_{1}$, resembling the fibroblast senescence-associated secretory phenotype (SASP) [28]. This proinflammatory profile suggests that senescent or senescent-like events likely occur in the central arterial wall with aging. Emerging evidence indicates that the AAASP likely delivers proinflammatory signals to exaggerate post-injury neointima formation and enhances the arterial calcification shift with aging [29-31].

\section{VSMC Apoptosis}

Apoptotic VSMCs are seldom detected in the grossly normal aged aortic wall $[13,21]$. Growing evidence indicates that isolated VSMCs from old donors are susceptible to the development of apoptosis via increased ROS production or NF-kB activation [21-22]. Apoptotic VSMCs directly promote arterial remodeling via activation of migration, proliferation of neighboring cells and collagen synthesis fueled by inflammatory molecules such as IL-6 [32]. Furthermore, an increased number of apoptotic VSMCs is closely associated with age-associated arterial stiffening and adverse remodeling [22, 32].

\section{VSMC Proliferation}

Intimal cell hyperplasia is a 'hallmark' of arterial aging in rats. Some subsets of old VSMCs enriched in cyclindependent kinase 4 (CDK4), proliferative nuclear antigen (PCNA) and Ki-67 have powerful proliferative capacity [33-35]. Old VSMCs are surrounded by and embedded in a ruptured matrix protein barrier that facilities their proliferation [36].

In rats and rabbits, old VSMCs proceed through the cell cycle faster than young cells [33-35]. The replication rate of old cultured VSMCs is increased, compared to those from their young counterparts [33-35]. Compared to young VSMCs, a greater percentage of old cultured VSMCs reside in the $S$ and G2/M phases, and a lower percentage in the G0/G1 phase $[33,35]$. In young cultured VSMCs, MFG-E8, a downstream molecule of Ang II signaling, induces phosphorylation of ERK1/2, augments levels of PCNA, CDK4 and PDGF/PDGFR signaling, increases 5-bromo-2'-deoxyuridine (BrdU) incorporation, and promotes proliferation via $\alpha v \beta 5$ integrin signaling [33]. MFG-E8 silencing, integrin inhibition, or the block- 
ade of ERK1/2 phosphorylation in young VSMCs reduces PCNA and CDK4 levels and decelerates the cell cycle S phase, resulting in a reduction in proliferative capacity [33]. Thus, MFG-E8 increases the expression of cell cycle molecules and facilitates proliferation in old VSMCs.

In mice, the basal levels of proliferative capacity of old VSMCs are markedly lower than that of young cells, due mainly to an increased production of ROS [37]. Under the PDGF challenged conditions, however, the proliferation rate of old VSMCs is dramatically accelerated compared to that in young cells [38].

Importantly, in humans, the proliferative and embryonic markers such as PCNA and embryonic form of smooth muscle myosin heavy chain (SMemb/MHC-B) are observed in old aortic intima, which is linked to Ang II signaling [21,39]. Indeed the proliferative capacity of isolated VSMCs from humans is increased with aging $[21,39]$.

\section{VSMC Migration and Invasion}

The migration/invasion of VSMCs from the arterial media to the intima is a key cellular event in the initiation and progression of age-associated diffuse intimal thickening. With advancing passage in culture, the invasive capacity of young VSMCs increases up to that of old cells, via increased activation of gelatinases induced by Ang II signaling [2-4, 39-43]. Old cultured VSMCs in early passage exhibit an exaggerated migration/invasion capacity compared to young VSMCs [39-43]. Exposure of early passage young VSMCs to Ang II, calpain-1, MFG-E8, PDGF-BB, or MCP-1 via activation of MMP-2 enhances their invasive capacity up to those levels observed in untreated old cells $[39,42]$. These age-associated VSMC invasive characteristics are blocked by the MMP inhibitor, GM6001; $\mathrm{AT}_{1}$ antagonist, losartan, and calpain-1 inhibitor, calpastatin [3943]. Furthermore, MFG-E8 silencing RNA substantially reduces MCP-1, PDGF and its receptor expression and consequently reduces VSMC invasion capacity [33, 43].

\section{VSMC ECM Production}

ECM not only structurally supports the artery, determining its mechanical behavior, but also regulates cellular proinflammatory phenotypes in the arterial wall with aging. Enhanced collagen deposition is a salient feature of ECM remodeling of the aging arterial wall [23, 39, 44-47]. VSMCs produce and maintain a complex meshwork of ECM, including collagen types I, II, and III. Increased Ang II signaling, via activation of TGF- $\beta_{1}$, is a powerful profibrogenic factor that governs the production of collagen molecules by VSMCs [44-47]. MMP-2-activated TGF- $\beta_{1} / T \beta R I I$ signaling is also involved in increased pro- duction of collagen I, II, and III, and the biologic glue fibronectin (FN), by old VSMCs [44, 47]. In addition, activation of intracellular calcium-dependent proteinase calpain-1 in old VSMCs, via MMP-2 activation, is involved in TGF- $\beta_{1}$ activation and increased collagen production [47].

VSMCs also produce collagen type IV, an element of the basement membrane, proteoglycans, and hyaluronic acid. These matrices become degenerated and accumulate within the arterial wall and function as a reservoir of bioactive factors, PDGF, oxLDL, and MMP-2/-9, which regulate behavior of VSMCs such as proliferation and migration with aging $[36,48-50]$. Importantly, these ECMs also modulate the process of calcification and neointima formation [48-51].

\section{VSMC Stiffness}

Increased aortic stiffness is an important feature of vascular aging. The elastic modulus (stiffness) measured by atomic force microscopy (AFM) of VSMCs isolated from old monkey aortae is increased compared to that of young VSMCs [52]. This increased VSMC stiffness is abolished by disassembling of the actin cytoskeleton with cytochalasin D [52]. Furthermore, VSMC stiffness is also higher in old than in young cells in a reconstituted tissue model [52]. In addition, the adhesion capacity of VSMCs from old arteries measured via AFM is increased versus that from young monkeys [53]. Thus, increased in vivo arterial stiffness with aging is attributable, not only to changes in ECM, but also to intrinsic changes in VSMC stiffness and adhesion capacity.

\section{Elastin Fragmentation}

Elastin fiber fracture along with the deposition of collagen is a hallmark of age-associated arterial remodeling. The close association of elastin and collagen to VSMCs in the aortic wall causes alterations in viscoelastic characteristics that account for many of its static and dynamic mechanical features. The elastin lamella and the contents of its adjacent interlamellar zone represent the unit of structure and function of the mammalian aortic wall, and are closely linked to elasticity, which progressively deteriorates with advancing age [23, 45]. Interestingly, recent studies reveal that the age-associated elastin degeneration and disassembly are tightly controlled by Ang II-associated micro-RNA 29 [54, 55]. In addition, a soluble fibrillin-1 bound latent TGF-binding protein is released during destruction of the elastin network and sets the stage for the stepwise activation of TGF- $\beta_{1}$ by Ang II signaling MMP-2, which, as noted, regulates collagen production of VSMCs $[45,56]$. 


\section{Adventitia}

The adventitia is an outermost layer of loose connective tissue, serving as the artery's final line of defense, functioning as a biological processing center for the retrieval, integration, storage and release of key regulators of arterial wall function [57]. It is composed of fibroblasts, pericytes, mast cells, and smooth muscle progenitor cells, and bundles of thick collagen, disoriented elastin fibers, vasa vasorum, nerve bundles, and lymphoid organization. Notably, adventitial remodeling is mainly determined by activation of fibroblasts known as myofibroblasts.

\section{(Myo)fibroblasts}

Fibroblasts are predominantly adventitial cells. With advancing age or under proinflammatory conditions, fibroblasts, ECs, and VSMCs are all activated and synthesize $\alpha$-smooth muscle actin ( $\alpha$-SMA), and become myofibroblasts [58-62]. Exposure of Ang II and Aldo to these cells enhances their inflammation, migration, and proliferation, likely contributing to arterial adverse remodeling and stiffening $[63,64]$.

\section{Aging Arterial Phenotype}

Aortic wall calcification, glyoxycation, and amyloidosis increases with advancing age, and aortic tissue becomes fertile soil for the pathogenesis of hypertension and atherosclerosis (fig. 1).

\section{Calcification}

Arterial calcification is a salient component of the ageassociated arterial remodeled phenotype. Old cultured VSMCs, phenotypically shifted from contractile to chondro-osseous differentiation, are able to produce large amounts of bone-like substrates, including collagen II in response to inflammatory factors such as calpain-1, and become biomineralized as calcification [47]. Overexpression of calpain-1 reduces the calcification inhibitors, tissue inhibitor type II of MMP-2 (TIMP-2), osteonectin, and osteopontin (OPN), and induces alkaline phosphatase and membrane type I of MMP-2 (MT1-MMP) activity in young VSMCs. This profile when calpain-1 is overexpressed resembles that of old VSMCs [47]. Impressively, calpain-1 activity, MMP-2 activity, and collagen II are upregulated within the human calcified aortae [47].

The activity of tissue transglutaminase (TG2), which catalyzes the cross-linking of proteins, increases in the old arterial wall [65] and is closely regulated by NO bioavail- ability [66, 67]. Activated TG2 upregulates calcification promoter genes, i.e. osteoblast master transcription factor runx2 and bone morphogen protein-2 (BMP-2), and downregulates the expression of calcification inhibitor genes, i.e. OPN within VSMCs [68]. Furthermore, TG2 activation is a key molecular event of programming VSMC transdifferentiation into osteoblast-like cells, contributing to arterial calcification and stiffening within old arterial walls $[67,68]$.

Interestingly, replicative senescence of VSMCs enhances the calcification through initiating the osteoplastic transition, which is also observed in the old arterial wall [69]. VSMC calcification was markedly enhanced in the senescent cells compared with that in the control young cells [30,31]. Genes highly expressed in osteoblasts, such as $A L P$, type I collagen, and $R U N X 2$, are significantly enhanced in the senescent VSMCs [30, 31]. These findings suggest that their osteoblastic transition is also involved in the senescence-mediated arterial calcification.

\section{Glycation}

Advanced non-enzymatic glycation of proteins, known as AGEs, produced via the Maillard reaction, increases in the arterial ECM and effects increased crosslinking of collagen. The abundant AGEs are observed in old arterial wall due to the local metabolic dysfunction of glucose even though circulating levels are in the normal range [70]. Increased AGEs are an important molecular event of age-associated arterial stiffening and proinflammation [2-5]. Additionally, AGEs recruit proinflammatory molecules TGF- $\beta_{1}$ and MCP-1 by interacting with their receptors for AGEs (RAGE) [2-5]. Importantly, methylglyoxal, a marker of AGEs, increased levels of circulating Aldo, renin, and Ang II, and local mRNA levels of angiotensinogen, $\mathrm{AT}_{1}$ receptor, and renin in the rat aorta, further facilitating vascular lesions $[71,72]$. Notably, a soluble RAGE, functioning as a decoy, contributes to the removal/detoxification of arterial AGEs, retardation of atherosclerosis, and improvement of arterial health [73].

\section{Amyloidosis}

Increased amyloid deposition is a characteristic of the inflamed aged arterial wall. A specific amyloid protein, known as medin, is detected in the aortic media in the majority of Caucasians over 50 years $[2,4,12]$. The medin fragment is $5.5 \mathrm{kDa}$ and is derived from the C2-like domain of MFG-E8. In addition, both medin and MFG-E8, in an amyloid protein complex, bind to tropoelastin, and regulate its elasticity $[2,4,12]$. Thus, MFG-E8/medin am- 
yloid is also a potential contributor to increased aortic wall proinflammation and stiffness that accompanies advancing age. Indeed, serum MFG-E8 levels correlate with levels of inflammatory molecules MCP-1 and TNF- $\alpha$ and with pulse wave velocity (PWV), an index of arterial stiffening in old humans [74].

\section{Central Arterial Aging and Ang II Signaling}

A growing body of evidence indicates that changes in Ang II and its downstream signaling significantly affect age-associated central arterial remodeling. Increased activation of the renin-angiotensin-aldosterone system and an increase in oxidative stress are both implicated in agerelated arterial remodeling, contributing to arterial proinflammation. The proinflammation within cells and ECM of the arterial wall consequently facilitate adverse arterial restructuring via alterations of arterial cells and ECM with advancing age (fig. 1). Chronic infusion of a physiologic relevant dose of Ang II to young rats (8-month-old) increases expression of molecular activity that comprise the proinflammation profile, e.g. MMP-2, MCP-1, calpain- 1 , TGF- $\beta_{1}$, nicotinamide adenine dinucleotide phosphate-oxidase (NADPH oxidase) and elicits the age-associated increase in aortic and coronary structural manifestations of old (30-month-old), untreated arteries, i.e. intimal and media thickening $[18,41]$. In addition, the $\alpha$-adrenoreceptor agonist, phenylephrine, increases arterial Ang II protein, causing MMP-2 activation and intimal and medial thickening [18].

\section{Interventions of Arterial Aging}

\section{Blockade of Ang II Signaling}

Ang II signaling plays a causal role in the process of arterial aging. Interestingly, chronic angiotensin-converting enzyme1 (ACE-1) inhibition and $\mathrm{AT}_{1}$ receptor blockade, beginning at an early age, markedly inhibit the expression of proinflammatory molecules, reduces stressinduced release of catecholamines, glucocorticoids, and vasopressin, and delays the progression of age-associated aortic remodeling such as elastin fragmentation and collagen deposition [75-77].

\section{Blockade of MMPs}

Age-associated arterial remodeling, due to arterial wall collagen deposition and elastin fragmentation, are associated with an increase in arterial blood pressure (BP). Chronic administration of a broad-spectrum MMP inhibitor, PD166793, markedly blunts the age-associated increases in aortic gelatinase and interstitial collagenase activity, and reduces the elastic fiber degeneration, collagen deposition, MCP-1 expression, TGF- $\beta_{1}$ activation, and SMAD-2/3 phosphorylation [45]. Interestingly, MMP inhibition also substantially diminishes pro-ET-1 activation and downregulates Ets-1 expression [45]. Importantly, MMP inhibition substantially retards the ageassociated increase in BP [45].

\section{Breakdown of AGEs}

AGEs are a major determinant of arterial stiffening with aging. Administration of ALT-711 (3-phenacyl-4,5dimethylthiazolium chloride), a non-enzymatic crosslink breaker of AGEs, for 39 weeks improved arterial compliance and ventricular function and optimized ventriculo-vascular coupling in older non-human primates [78]. Moreover, ALT-711 treatment for 56 days significantly improved total arterial compliance and lower pulse pressure in older humans with vascular stiffening [79]. Thus, increased collagen cross-linking via glycoxidation is an important molecular event of age-associated arterial stiffening.

\section{Calorie Restriction and SIRT1 Activity}

Calorie restriction (CR) is a dietary approach to improve health and slow the aging process in both experimental animals and humans. The expression of SIRT1, a longevity gene, decreases with aging within the arterial wall, contributing to arterial proinflammation, endothelial dysfunction, and stiffening [7]. Interestingly, CR retards EC apoptosis/senescence aging features and increases lifespan in rodents, which is closely associated with an increase in SIRT1 activity [80]. Resveratrol, an activator of SIRT1, mimics CR, retarding arterial wall adverse remodeling and lipid deposition in the perivascular space of the heart in rodents fed a high-fat diet via increase of insulin sensitivity and mitochondria function [81]. Impressively, the AAASP in monkey VSMCs is substantially reversed by resveratrol [28]. Importantly, overexpression of SIRT1 inhibits both VSMC AT ${ }_{1}$ expression and NADPH oxidase activation and blunts Ang II-induced hypertension [82]. These findings suggest that CR/ resveratrol treatment retards aging likely via an inhibition of Ang II-driven oxidation.

\section{Physical Conditioning and Blockade of \\ Proinflammation}

It is known in humans that habitual physical activity leads to improvement in arterial structure and function with aging by increasing resistance to the effects of car- 
diovascular risk factors like oxLDL cholesterol [61, 62, 83]. Several studies in both aging rodents and humans have demonstrated that vascular endothelial dysfunction and stiffening are improved with voluntary aerobic exercise through a pronounced reduction of the inflammation markers TNF- $\alpha$, NF- $\kappa B$, NADPH oxidase, and TGF- $\beta_{1}$, as well as an enhancement of NO bioavailability and Nrf2 activity $[61,62,83]$.

\section{Concluding Remarks}

Arterial aging is a journey into subclinical adverse arterial remodeling. Disruption of the endothelium, and augmented VSMC migration/proliferation/senescence, ECM deposition, elastin fracture, and matrix glycoxidative modifications, are characteristics of the arterial aging phenotype. These adverse cellular events are recapitulated in ex- perimental young animals in response to chronic Ang II infusion, and are attenuated in old animals via interference of proinflammatory signaling in vivo. Since the age-associated molecular and cellular events set a stage for the pathogenesis of hypertension and atherosclerosis, interventions of arterial proinflammation with aging may effectively curb the epidemic of cardiovascular disease in the elderly.

\section{Acknowledgement}

This research was supported by the Intramural Research Program of the National Institute on Aging, National Institutes of Health.

\section{Disclosure Statement}

The authors have no conflicts of interest to disclose.

\section{References}

1 Go AS, Mozaffarian D, Roger VL, Benjamin EJ, Berry JD, Blaha MJ, Dai S, Ford ES, Fox CS, Franco S, Fullerton HJ, Gillespie C, Hailpern SM, Heit JA, Howard VJ, Huffman MD, Judd SE, Kissela BM, Kittner SJ, Lackland DT, Lichtman JH, Lisabeth LD, Mackey RH, Magid DJ, Marcus GM, Marelli A, Matchar DB, McGuire DK, Mohler ER 3rd, Moy CS, Mussolino ME, Neumar RW, Nichol G, Pandey DK, Paynter NP, Reeves MJ, Sorlie PD, Stein J, Towfighi A, Turan TN, Virani SS, Wong ND, Woo D, Turner MB; American Heart Association Statistics Committee and Stroke Statistics Subcommittee. Heart disease and stroke statistics - 2014 update: a report from the American Heart Association. Circulation 2014;129:e28-e292.

- Wang M, Jiang L, Monticone RE, Lakatta EG: Proinflammation: the key to arterial aging. Trends Endocrinol Metab 2014;25:72-79.

-3 Wang M, Monticone RE, Lakatta EG: Arterial aging: a journey into subclinical arterial disease. Curr Opin Nephrol Hypertens 2010;19: 201-207.

4 Lakatta EG: The reality of aging viewed from the arterial wall. Artery Res 2013;7:73-80.

5 Wang M, Khazan B, Lakatta EG: Central arterial aging and angiotensin II signaling. Curr Hypertens Rev 2010;6:266-281.

-6 Virmani R, Avolio AP, Mergner WJ, Robinowitz M, Herderick EE, Cornhill JF, Guo SY, Liu TH, Ou DY, O'Rourke M: Effect of aging on aortic morphology in populations with high and low prevalence of hypertension and atherosclerosis. Comparison between occidental and Chinese communities. Am J Pathol 1991;139:1119-1129.
7 Clarkson TB, Adams, MR, Weingand KW, Miller LC, Heydrick S: Effect of age on atherosclerosis progression in non-human primates; in Bates SR, Ganghoff EC (eds): Atherogenesis and Aging. New York, Springer, 1987, pp 57-71.

8 Ruiz-García J, Lerman A, Weisz G, Maehara A, Mintz GS, Fahy M, Xu K, Lansky AJ, Cristea E, Farah TG, Teles R, Botker HE, Templin B, Zhang Z, de Bruyne B, Serruys PW, Stone GW: Age- and gender-related changes in plaque composition in patients with acute coronary syndrome: the PROSPECT study. EuroIntervention 2012;8:929-938.

-9 Spagnoli LG, Orlandi A, Mauriello A, Santeusanio G, de Angelis C, Lucreziotti R, Ramacci MT: Aging and atherosclerosis in the rabbit. 1. Distribution, prevalence and morphology of atherosclerotic lesions. Atherosclerosis 1991;89:11-24.

10 Fleg JL, Forman DE, Berra K, Bittner V, Blumenthal JA, Chen MA, Cheng S, Kitzman DW, Maurer MS, Rich MW, Shen WK, Williams MA, Zieman SJ; American Heart Association Committees on Older Populations and Exercise Cardiac Rehabilitation and Prevention of the Council on Clinical Cardiology, Council on Cardiovascular and Stroke Nursing, Council on Lifestyle and Cardiometabolic Health. Secondary prevention of atherosclerotic cardiovascular disease in older adults: a scientific statement from the American Heart Association. Circulation 2013;128:2422-2446.

11 Csiszar A, Wang M, Lakatta EG, Ungvari Z: Inflammation and endothelial dysfunction during aging: role of NF- $\kappa$ B. J Appl Physiol (1985) 2008;105:1333-1341.
12 Wang M, Wang HH, Lakatta EG: Milk fat globule epidermal growth factor VIII signaling in arterial wall remodeling. Curr Vasc Pharmacol 2013;11:768-776.

13 Asai K, Kudej RK, Shen YT, Yang GP, Takagi G, Kudej AB, Geng YJ, Sato N, Nazareno JB, Vatner DE, Natividad F, Bishop SP, Vatner SF: Peripheral vascular endothelial dysfunction and apoptosis in old monkeys. Arterioscler Thromb Vasc Biol 2000;20:1493-1499.

14 Brandes RP, Fleming I, Busse R: Endothelial aging. Cardiovasc Res 2005;66:286-294.

15 Matsui-Hirai H, Hayashi T, Yamamoto S, Ina $\mathrm{K}$, Maeda $\mathrm{M}$, Kotani $\mathrm{H}$, Iguchi $\mathrm{A}$, Ignarro LJ, Hattori Y: Dose-dependent modulatory effects of insulin on glucose-induced endothelial senescence in vitro and in vivo: a relationship between telomeres and nitric oxide. J Pharmacol Exp Ther 2011;337:591599.

16 Yepuri G, Velagapudi S, Xiong Y, Rajapakse AG, Montani JP, Ming XF, Yang Z: Positive crosstalk between arginase-II and S6K1 in vascular endothelial inflammation and aging. Aging Cell 2012;11:1005-1016.

17 Orimo M, Minamino T, Miyauchi H, Tateno K, Okada S, Moriya J, Komuro I: Protective role of SIRT1 in diabetic vascular dysfunction. Arterioscler Thromb Vasc Biol 2009;29: 889-894.

18 Wang M, Zhang J, Spinetti G, Jiang LQ, Monticone R, Zhao D, Cheng L, Krawczyk M, Talan M, Pintus G, Lakatta EG: Angiotensin II activates matrix metalloproteinase type II and mimics age-associated carotid arterial remodeling in young rats. Am J Pathol 2005;167: 1429-1442. 
19 McCrann DJ, Yang D, Chen H, Carroll S, Ravid K: Upregulation of Nox4 in the aging vasculature and its association with smooth muscle cell polyploidy. Cell Cycle 2009;8:902908.

20 Yang D, McCrann DJ, Nguyen H, St Hilaire C, DePinho RA, Jones MR, Ravid K: Increased polyploidy in aortic vascular smooth muscle cells during aging is marked by cellular senescence. Aging Cell 2007;6:257-260.

-21 Ferlosio A, Arcuri G, Doldo E, Scioli MG, De Falco S, Spagnoli LG, Orlandi A: Age-related increase of stem marker expression influences vascular smooth muscle cell properties. Atherosclerosis 2012;224:51-57.

-22 Zhou RH, Vendrov AE, Tchivilev I, Niu XL, Molnar KC, Rojas M, Carter JD, Tong H, Stouffer GA, Madamanchi NR, Runge MS: Mitochondrial oxidative stress in aortic stiffening with age: the role of smooth muscle cell function. Arterioscler Thromb Vasc Biol 2012;32:745-755.

23 Wang M, Lakatta EG: Altered regulation of matrix metalloproteinase-2 in aortic remodeling during aging. Hypertension 2002;39: 865-873.

24 Shekhonin BV, Domogatsky SP, Muzykantov VR, Idelson GL, Rukosuev VS: Distribution of type I, III, IV and V collagen in normal and atherosclerotic human arterial wall: immunomorphological characteristics. Coll Relat Res 1985;5:355-368.

25 Kunieda T, Minamino T, Nishi J, Tateno K, Oyama T, Katsuno T, Miyauchi H, Orimo M, Okada S, Takamura M, Nagai T, Kaneko S, Komuro I: Angiotensin II induces premature senescence of vascular smooth muscle cells and accelerates the development of atherosclerosis via a p21-dependent pathway. Circulation 2006;114:953-960.

-26 Herbert KE, Mistry Y, Hastings R, Poolman T, Niklason L, Williams B: Angiotensin IImediated oxidative DNA damage accelerates cellular senescence in cultured human vascular smooth muscle cells via telomere-dependent and independent pathways. Circ Res 2008;102:201-208.

-27 Vafaie F, Yin H, O'Neil C, Nong Z, Watson A, Arpino JM, Chu MW, Wayne Holdsworth D, Gros R, Pickering JG: Collagenase-resistant collagen promotes mouse aging and vascular cell senescence. Aging Cell 2014;13:121-130.

-28 Csiszar A, Sosnowska D, Wang M, Lakatta EG, Sonntag WE, Ungvari Z: Age-associated proinflammatory secretory phenotype in vascular smooth muscle cells from the non-human primate Macaca mulatta: reversal by resveratrol treatment. J Gerontol A Biol Sci Med Sci 2012;67:811-820.

29 Khan SJ, Pham S, Wei Y, Mateo D, St-Pierre M, Fletcher TM, Vazquez-Padron RI: Stressinduced senescence exaggerates postinjury neointimal formation in the old vasculature. Am J Physiol Heart Circ Physiol 2010; 298:H66-H74.
30 Burton DG, Matsubara H, Ikeda K: Pathophysiology of vascular calcification: pivotal role of cellular senescence in vascular smooth muscle cells. Exp Gerontol 2010;45:819-824.

- 31 Nakano-Kurimoto R, Ikeda K, Uraoka M, Nakagawa Y, Yutaka K, Koide M, Takahashi T, Matoba S, Yamada H, Okigaki M, Matsubara $\mathrm{H}$ : Replicative senescence of vascular smooth muscle cells enhances the calcification through initiating the osteoblastic transition. Am J Physiol Heart Circ Physiol 2009; 297:H1673-H1684.

$32 \mathrm{Yu} \mathrm{H}$, Clarke MC, Figg N, Littlewood TD, Bennett MR: Smooth muscle cell apoptosis promotes vessel remodeling and repair via activation of cell migration, proliferation, and collagen synthesis. Arterioscler Thromb Vasc Biol 2011;31:2402-2409.

33 Wang M, Fu Z, Wu J, Zhang J, Jiang L, Khazan B, Telljohann R, Zhao M, Krug AW, Pikilidou M, Monticone RE, Wersto R, Van Eyk J, Lakatta EG: MFG-E8 activates proliferation of vascular smooth muscle cells via integrin signaling. Aging Cell 2012;11:500-508.

34 Gennaro G, Ménard C, Giasson E, Michaud SE, Palasis M, Meloche S, Rivard A: Role of p44/p42 MAP kinase in the age-dependent increase in vascular smooth muscle cell proliferation and neointimal formation. Arterioscler Thromb Vasc Biol 2003;23:204-210.

- 35 Rivard A, Principe N, Andrés V: Age-dependent increase in c-fos activity and cyclin A expression in vascular smooth muscle cells. A potential link between aging, smooth muscle cell proliferation and atherosclerosis. Cardiovasc Res 2000;45:1026-1034

36 Newby AC: Matrix metalloproteinases regulate migration, proliferation, and death of vascular smooth muscle cells by degrading matrix and non-matrix substrates. Cardiovasc Res 2006;69:614-624.

37 Moon SK, Thompson LJ, Madamanchi N, Ballinger S, Papaconstantinou J, Horaist C, Runge MS, Patterson C: Aging, oxidative responses, and proliferative capacity in cultured mouse aortic smooth muscle cells. Am J Physiol Heart Circ Physiol 2001;280:H2779-H2788.

38 Vazquez-Padron RI, Lasko D, Li S, Louis L, Pestana IA, Pang M, Liotta C, Fornoni A, Aitouche A, Pham SM: Aging exacerbates neointimal formation, and increases proliferation and reduces susceptibility to apoptosis of vascular smooth muscle cells in mice. J Vasc Surg 2004;40:1199-1207.

39 Wang M, Zhang J, Jiang LQ, Spinetti G, Pintus G, Monticone R, Kolodgie FD, Virmani R, Lakatta EG: Proinflammatory profile within the grossly normal aged human aortic wall. Hypertension 2007;50:219-227.

40 Pauly RR, Passaniti A, Bilato C, Monticone R, Cheng L, Papadopoulos N, Gluzband YA, Smith L, Weinstein C, Lakatta EG, et al: Migration of cultured vascular smooth muscle cells through a basement membrane barrier requires type IV collagenase activity and is inhibited by cellular differentiation. Circ Res 1994;75:41-54.
41 Wang M, Zhang J, Spinetti G, Jiang LQ, Monticone R, Zhao D, Cheng L, Krawczyk M, Talan M, Pintus G, Lakatta EG: Angiotensin II activates matrix metalloproteinase type II and mimics age-associated carotid arterial remodeling in young rats. Am J Pathol 2005;167: 1429-1442.

42 Spinetti G, Wang M, Monticone R, Zhang J, Zhao D, Lakatta EG: Rat aortic MCP-1 and its receptor CCR2 increase with age and alter vascular smooth muscle cell function. Arterioscler Thromb Vasc Biol 2004;24:13971402.

43 Fu Z, Wang M, Gucek M, Zhang J, Wu J, Jiang L, Monticone RE, Khazan B, Telljohann R, Mattison J, Sheng S, Cole RN, Spinetti G, Pintus G, Liu L, Kolodgie FD, Virmani R, Spurgeon $\mathrm{H}$, Ingram DK, Everett AD, Lakatta EG, Van Eyk JE: Milk fat globule protein epidermal growth factor-8:a pivotal relay element within the angiotensin II and monocyte chemoattractant protein- 1 signaling cascade mediating vascular smooth muscle cells invasion. Circ Res 2009;104:1337-1346.

44 Wang M, Zhao D, Spinetti G, Zhang J, Jiang LQ, Pintus G, Monticone R, Lakatta EG: Matrix metalloproteinase 2 activation of transforming growth factor- $\beta_{1}$ (TGF- $\beta_{1}$ ) and TGF$\beta_{1}$-type II receptor signaling within the aged arterial wall. Arterioscler Thromb Vasc Biol 2006;26:1503-1509.

45 Wang M, Zhang J, Telljohann R, Jiang L, Wu J, Monticone RE, Kapoor K, Talan M, Lakatta EG: Chronic matrix metalloproteinase inhibition retards age-associated arterial proinflammation and increase in blood pressure. Hypertension 2012;60:459-466.

46 Wang M, Zhang J, Walker SJ, Dworakowski R, Lakatta EG, Shah AM: Involvement of $\mathrm{NADPH}$ oxidase in age-associated cardiac remodeling. J Mol Cell Cardiol 2010;48:765772 .

47 Jiang L, Zhang J, Monticone RE, Telljohann $\mathrm{R}, \mathrm{Wu}$ J, Wang M, Lakatta EG: Calpain-1 regulation of matrix metalloproteinase 2 activity in vascular smooth muscle cells facilitates age-associated aortic wall calcification and fibrosis. Hypertension 2012;60:1192-1199.

48 Vigetti D, Viola M, Karousou E, Rizzi M, Moretto P, Genasetti A, Clerici M, Hascall VC, De Luca G, Passi A: Hyaluronan-CD44ERK1/2 regulate human aortic smooth muscle cell motility during aging. J Biol Chem 2008;283:4448-4458.

49 Tovar AM, Cesar DC, Leta GC, Mourão PA: Age-related changes in populations of aortic glycosaminoglycans: species with low affinity for plasma low-density lipoproteins, and not species with high affinity, are preferentially affected. Arterioscler Thromb Vasc Biol 1998; 18:604-614.

50 Feyzi E, Saldeen T, Larsson E, Lindahl U, Salmivirta M: Age-dependent modulation of heparan sulfate structure and function. J Biol Chem 1998;273:13395-13398. 
51 Chajara A, Delpech B, Courel MN, Leroy M, Basuyau JP, Lévesque $\mathrm{H}$ : Effect of aging on neointima formation and hyaluronan, hyaluronidase and hyaluronectin production in injured rat aorta. Atherosclerosis 1998;138: 53-64.

-52 Qiu H, Zhu Y, Sun Z, Trzeciakowski JP, Gansner M, Depre C, Resuello RR, Natividad FF, Hunter WC, Genin GM, Elson EL, Vatner DE, Meininger GA, Vatner SF: Short communication: vascular smooth muscle cell stiffness as a mechanism for increased aortic stiffness with aging. Circ Res 2010;107:615-619.

-53 Zhu Y, Qiu H, Trzeciakowski JP, Sun Z, Li Z, Hong Z, Hill MA, Hunter WC, Vatner DE, Vatner SF, Meininger GA: Temporal analysis of vascular smooth muscle cell elasticity and adhesion reveals oscillation waveforms that differ with aging. Aging Cell 2012;11:741750.

-54 Boon RA, Seeger T, Heydt S, Fischer A, Hergenreider E, Horrevoets AJ, Vinciguerra M, Rosenthal N, Sciacca S, Pilato M, van Heijningen P, Essers J, Brandes RP, Zeiher AM, Dimmeler S: MicroRNA-29 in aortic dilation: implications for aneurysm formation. Circ Res 2011;109:1115-1119.

- 55 Ott CE, Grünhagen J, Jäger M, Horbelt D, Schwill S, Kallenbach K, Guo G, Manke T, Knaus P, Mundlos S, Robinson PN: MicroRNAs differentially expressed in postnatal aortic development downregulate elastin via $3^{\prime}$ UTR and coding-sequence binding sites. PLoS One 2011;6:e16250.

56 Olivieri J, Smaldone S, Ramirez F: Fibrillin assemblies: extracellular determinants of tissue formation and fibrosis. Fibrogenesis Tissue Repair 2010;3:24.

57 Havelka GE, Kibbe MR: The vascular adventitia: its role in the arterial injury response. Vasc Endovascular Surg 2011;45:381-390.

- 58 Villaschi S, Nicosia RF: Paracrine interactions between fibroblasts and endothelial cells in a serum-free coculture model. Modulation of angiogenesis and collagen gel contraction. Lab Invest 1994;71:291-299.

59 Lin Z, Liu L, Xi Z, Huang J, Lin B: Singlewalled carbon nanotubes promote rat vascular adventitial fibroblasts to transform into myofibroblasts by SM22- $\alpha$ expression. Int J Nanomedicine 2012;7:4199-4206.

-60 Sartore S, Chiavegato A, Faggin E, Franch R, Puato M, Ausoni S, Pauletto P: Contribution of adventitial fibroblasts to neointima formation and vascular remodeling: from innocent bystander to active participant. Circ Res 2001; 89:1111-1121.

61 Fleenor BS, Marshall KD, Durrant JR, Lesniewski LA, Seals DR: Arterial stiffening with ageing is associated with transforming growth factor- $\beta_{1}$-related changes in adventitial collagen: reversal by aerobic exercise. J Physiol 2010;588:3971-3982.
62 Lesniewski LA, Durrant JR, Connell ML, Henson GD, Black AD, Donato AJ, Seals DR: Aerobic exercise reverses arterial inflammation with aging in mice. Am J Physiol Heart Circ Physiol 2011;301:H1025-H1032.

63 Jin X, Fu GX, Li XD, Zhu DL, Gao PJ: Expression and function of osteopontin in vascular adventitial fibroblasts and pathological vascular remodeling. PLoS One 2011;6:e23558.

64 Jin X, Ge X, Zhu DL, Yan C, Chu YF, Chen WD, Liu J, Gao PJ: Expression and function of vascular endothelial growth factor receptors (Flt-1 and Flk-1) in vascular adventitial fibroblasts. J Mol Cell Cardiol 2007;43:292300.

65 Santhanam L, Tuday EC, Webb AK, Dowzicky P, Kim JH, Oh YJ, Sikka G, Kuo M, Halushka MK, Macgregor AM, Dunn J, Gutbrod S, Yin D, Shoukas A, Nyhan D, Flavahan NA, Belkin AM, Berkowitz DE: Decreased Snitrosylation of tissue transglutaminase contributes to age-related increases in vascular stiffness. Circ Res 2010;107:117-125.

66 Jandu SK, Webb AK, Pak A, Sevinc B, Nyhan D, Belkin AM, Flavahan NA, Berkowitz DE, Santhanam L: Nitric oxide regulates tissue transglutaminase localization and function in the vasculature. Amino Acids 2013;44:261269.

67 Jung SM, Jandu S, Steppan J, Belkin A, An SS, Pak A, Choi EY, Nyhan D, Butlin M, Viegas K, Avolio A, Berkowitz DE, Santhanam L: Increased tissue transglutaminase activity contributes to central vascular stiffness in eNOS knockout mice. Am J Physiol Heart Circ Physiol 2013;305:H803-H810.

68 Johnson KA, Polewski M, Terkeltaub RA: Transglutaminase 2 is central to induction of the arterial calcification program by smooth muscle cell. Circ Res 2008;102:529-537.

69 Leopold JA: Vascular calcification: an age-old problem of old age. Circulation 2013;127: 2380-2382.

70 Hallam KM, Li Q, Ananthakrishnan R, Kalea A, Zou YS, Vedantham S, Schmidt AM, Yan SF, Ramasamy R: Aldose reductase and AGERAGE pathways: central roles in the pathogenesis of vascular dysfunction in aging rats. Aging Cell 2010;9:776-784.

71 Dhar I, Dhar A, Wu L, Desai KM: Methylglyoxal, a reactive glucose metabolite, increases renin angiotensin aldosterone and blood pressure in male Sprague-Dawley rats. Am J Hypertens 2014;27:308-316.

72 Schupp N, Schinzel R, Heidland A, Stopper H: Genotoxicity of advanced glycation end products: involvement of oxidative stress and of angiotensin II type 1 receptors. Ann NY Acad Sci 2005; 1043:685-695.
3 Lee D, Lee KH, Park H, Kim SH, Jin T, Cho S, Chung JH, Lim S, Park S: The effect of soluble RAGE on inhibition of angiotensin ii-mediated atherosclerosis in apolipoprotein E deficient mice. PLoS One 2013;8:e69669.

74 Cheng M, Li BY, Li XL, Wang Q, Zhang JH, Jing XJ, Gao HQ: Correlation between serum lactadherin and pulse wave velocity and cardiovascular risk factors in elderly patients with type 2 diabetes mellitus. Diabetes Res Clin Pract 2012;95:125-131.

75 Baiardi G, Bregonzio C, Jezova M, Armando I, Saavedra JM: Angiotensin II $\mathrm{AT}_{1}$ receptor blockade prolongs the lifespan of spontaneously hypertensive rats and reduces stress-induced release of catecholamines, glucocorticoids, and vasopressin. Ann NY Acad Sci 2004;1018:131-136.

76 Huang W, Alhenc Gelas F, Osborne-Pellegrin MJ: Protection of the arterial internal elastic lamina by inhibition of the renin-angiotensin system in the rat. Circ Res 1998;82:879-890.

-77 Basso N, Cini R, Pietrelli A, Ferder L, Terragno NA, Inserra F: Protective effect of longterm angiotensin II inhibition. Am J Physiol Heart Circ Physiol 2007;293:H1351-H358.

78 Vaitkevicius PV, Lane M, Spurgeon H, Ingram DK, Roth GS, Egan JJ, Vasan S, Wagle DR, Ulrich P, Brines M, Wuerth JP, Cerami A, Lakatta EG: A cross-link breaker has sustained effects on arterial and ventricular properties in older rhesus monkeys. Proc Natl Acad Sci USA 2001;98:1171-1175.

79 Kass DA, Shapiro EP, Kawaguchi M, Capriotti AR, Scuteri A, deGroof RC, Lakatta EG: Improved arterial compliance by a novel advanced glycation end-product crosslink breaker. Circulation 2001;104:1464-1470.

80 Chang HC, Guarente L: SIRT1 and other sirtuins in metabolism. Trends Endocrinol Metab 2014;25:138-145.

81 Baur JA, Pearson KJ, Price NL, Jamieson HA, Lerin C, Kalra A, Prabhu VV, Allard JS, Lopez-Lluch G, Lewis K, Pistell PJ, Poosala S, Becker KG, Boss O, Gwinn D, Wang M, Ramaswamy S, Fishbein KW, Spencer RG, Lakatta EG, Le Couteur D, Shaw RJ, Navas P, Puigserver P, Ingram DK, de Cabo R, Sinclair DA: Resveratrol improves health and survival of mice on a high-calorie diet. Nature 2006; 444:337-342.

82 Miyazaki R, Ichiki T, Hashimoto T, Inanaga $\mathrm{K}$, Imayama I, Sadoshima J, Sunagawa K: SIRT1, a longevity gene, downregulates angiotensin II type 1 receptor expression in vascular smooth muscle cells. Arterioscler Thromb Vasc Biol 2008;28:1263-1269.

83 Seals DR, Walker AE, Pierce GL, Lesniewski LA: Habitual exercise and vascular ageing. J Physiol 2009;587:5541-5549. 